\title{
SOME CASES OF MACRO-EPIBIOSIS ON THE INVASIVE CRAYFISH ORCONECTES LIMOSUS IN THE CZECH REPUBLIC
}

\author{
Z. ĎURIŠ (1), I. HORKÁ (1), J. KRISTIAN (1), P. KOZÁK (2)
}

(1) Department of Biology, University of Ostrava, Chittussiho 10, Ostrava, CZ-710 00, Czech Republic. E-Mail: Zdenek.Duris@osu.cz

(2) Research Institute of Fish Culture and Hydrobiology, University of South Bohemia, Zátiší 728/II, Vodňany, CZ-389 25, Czech Republic

Reçu le 23 juin 2005

Accepté le 2 février 2006

Received June 23, 2005

Accepted February 2, 2006

\begin{abstract}
Several cases of epibiosis by macro-invertebrates on Orconectes limosus were recorded during our research on the biology of populations of this invasive crayfish species in the Czech Republic. (1) In 2001, we observed a high infestation of $O$. limosus by native species of branchiobdellidan worms (Annelida: Branchiobdellidae) in the river Elbe at Obříství (Central Bohemia). Four European Branchiobdella species were collected and identified from three crayfish specimens: B. pentodonta $(52 \%)$, B. balcanica $(24 \%)$, $B$. parasita (18\%) and $B$. hexodonta $(6 \%)$. In 2003 , only a single crayfish was found bearing branchiobdellidans (5 specimens of $B$. parasita only) in the same locality. No branchiobdellidans on $\mathrm{O}$. limosus have been confirmed since. (2) A flooded sandpit Lhota near Brandýs nad Labem is the only Czech locality where the settlement of Dreissena polymorpha (Mollusca, Bivalvia) on an O. limosus body was recorded. The crayfish lost the bivalves by moulting in summer; new mussels had settled by late summer and early autumn. (3) Females of the fish louse Argulus cf. foliaceus (Crustacea: Branchiura) lay egg-strings on any hard substrate, including the crayfish exoskeleton. Such egg-masses were found on up to $65 \%$ of $O$. limosus specimens in the above-mentioned sandpit. (4) Bryozoan colonies of Plumatella repens were found twice on crayfish in the rivers Elbe (Labe) and Cidlina.
\end{abstract}

Key-words: Orconectes limosus, spiny-cheek crayfish, epibiosis, Branchiobdella, Dreissena polymorpha, Branchiura, Argulus foliaceus, Bryozoa, Plumatella repens, Czech Republic.

\section{QUELQUES CAS DE MACRO-ÉPIBIOSE CHEZ L'ÉCREVISSE INVASIVE ORCONECTES LIMOSUS EN RÉPUBLIQUE TCHĖQUE}

\section{RÉSUMÉ}

Au cours de nos recherches sur la biologie des populations d'écrevisse invasive Orconectes limosus présentes en République tchèque, nous avons observé plusieurs cas d'épibioses par des macroinvertébrés sur cette écrevisse. (1) En 2001, nous avons observé un taux d'infestation élevé chez $O$. limosus par des vers (Annelida: Branchiobdellidae) dans l'Elbe à Obříství. Quatre espèces européennes de Branchiobdella ont été récoltées et identifiées en examinant trois spécimens d'écrevisses: B. pentodonta (52\%), B. balcanica 
(24\%), B. parasita (18\%) et $B$. hexodonta (6\%). En 2003, une seule écrevisse porteuse de Branchiobdella (5 spécimens de la seule espèce $B$. parasita) a été trouvée dans la même localité. Aucun Branchiobdellidae n'a été trouvé par la suite sur O. limosus. (2) La carrière de sable innondée de Lhota près de Brandýs nad Labem est la seule localité tchèque où la fixation de Dreissena polymorpha (Mollusca, Bivalvia) sur le corps de O. limosus a été observée. Les écrevisses perdent les bivalves lors de la mue estivale mais de nouvelles moules se fixent sur leur corps en fin d'été et en début d'automne. (3) Des femelles du pou des poissons Argulus cf. foliaceus (Crustacea: Branchiura) déposent leurs pontes sur une variété de substrats durs, y compris sur l'exosquelette des écrevisses. De telles pontes ont été observées sur non moins de $65 \%$ des spécimens d'O. limosus dans la carrière de sable déjà mentionnée. (4) Des colonies du bryozoaire Plumatella repens, ont été trouvées deux fois sur des écrevisses au cours de nos recherches sur les rivières Elbeet Cidlina.

Mots-clés: Orconectes limosus, République tchèque, épibiose, Branchiobdella, Dreissena polymorpha, Argulus foliaceus, bryozoaires, Plumatella repens.

\section{INTRODUCTION}

The rise in understanding of crayfish as important bio-indicator of the quality of aquatic environment during the period of the European "crayfish crisis", as well as growing demands on crayfish culture, has increasingly drawn the attention of farmers and investigators to organisms that cause diseases of these crustaceans, or co-occur with them. Wider studies have been devoted to fungal, bacterial and protozoan pathogens (EVANS and EDGERTON, 2002; EDGERTON et al., 2002, 2004), though endoparasites (Trematoda, Cestoda and Acanthocephala) are known as well (ŠTĚPÁN 1932-33; ALDERMAN and POLGLASE, 1988; EVANS and EDGERTON, 2002). In the shadow of studies of crayfish plague and other highly important pathogens, reports of epizoic organisms living or occasionally occurring on crayfish are much less frequent, apart from those on branchiobdellidan worms (HOLT, 1975; GELDER, 1996, 1999; ALDERMAN and POLGLASE, 1988).

We have recorded several cases of epibioses on crayfish during a recent study on the biology of the invading spiny-cheek crayfish Orconectes limosus, which was carried out in the Czech Republic in 2003-2005. The present paper reports details on selected macroinvertebrate groups found in association with $O$. limosus during the survey.

Although we have observed a variety of macroscopic organisms during the study, including green algae, larvae of chironomid dipterans (Insecta), ostracod and harpacticoid crustaceans, gastropod mollusk eggs, etc., here we focus on four systematic groups of macroinvertebrate organisms only - branchiobdellidan worms (Annelida), bivalve mollusks, fish lice (Crustacea), and bryozoans. Branchiobdellidans are known to be frequently associated with crayfish (HOLT, 1975; GELDER, 1996) but are rarely reported from the spiny-cheek crayfish; the other groups have been only scarcely recorded, or not reported from crayfish at all.

\section{MATERIAL AND METHODS}

About 60 localities in the Czech Republic were examined during a survey on the biology and distribution of Orconectes limosus in 2003-2005. The localities reported in this study (Figure 1) are listed in Table I.

Crayfish were collected by hand in running waters and by scuba diving in standing waters, and preserved in alcohol. All crayfish were measured and weighed, sex and injuries were noted, and associated epibionts were photographed and collected. In the latter part of the study, branchiobdellidan worms and zebra mussels were collected (and preserved in $70 \%$ ethanol), or noted, from different microhabitats on the crayfish body. 


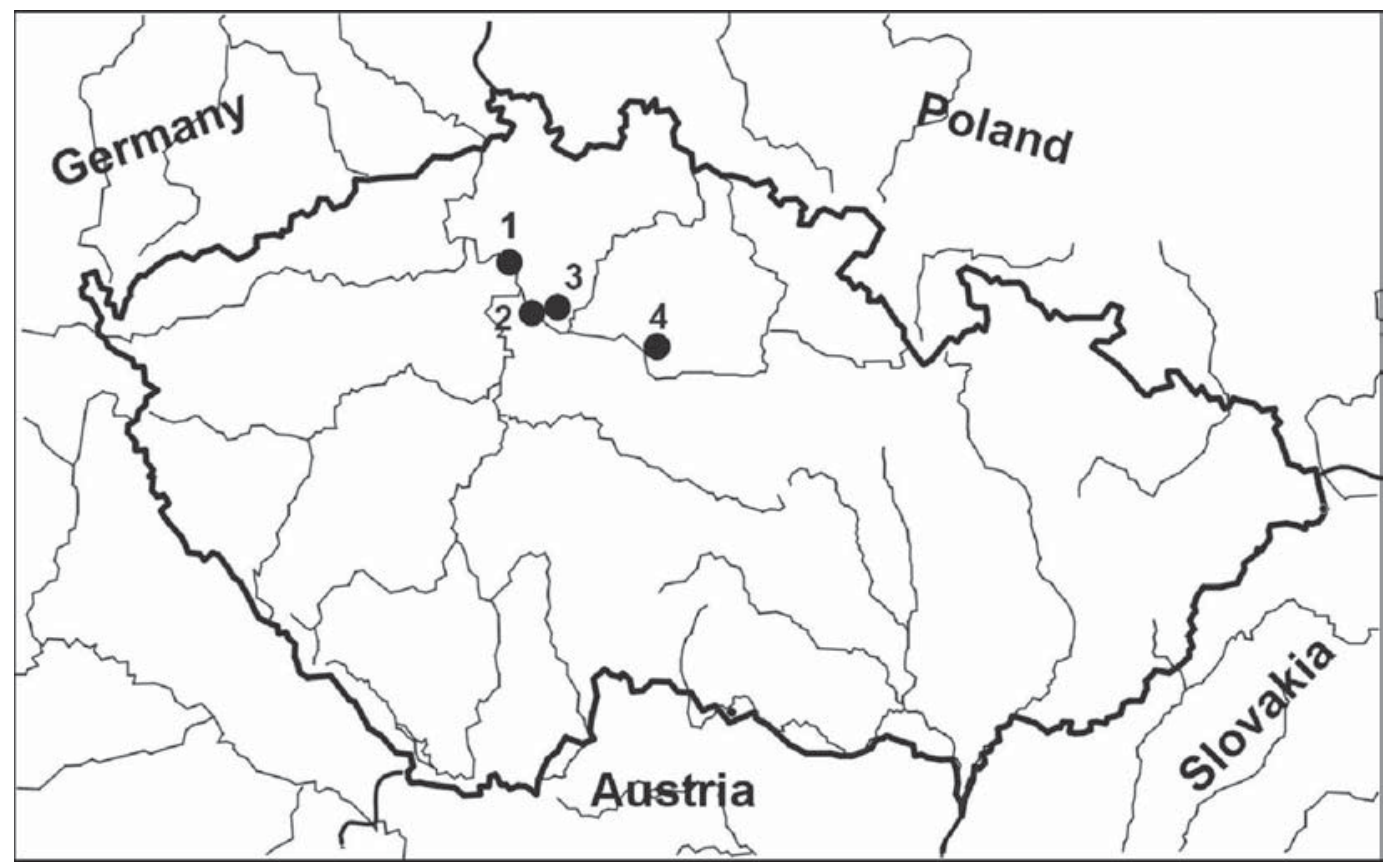

Figure 1

Localities in the Czech Republic where epibioses on Orconectes limosus documented in this study occurred. Corresponding epibionts are listed in parentheses.

1 - Hněvice, river Elbe (Plumatella); 2 - Obříství, river Elbe (Branchiobdella);

3 - sandpit Lhota (Dreissena, Argulus); 4 - river Cidlina (Plumatella).

Figure 1

Localités en République tchèque où les épibioses sur des Orconectes limosus étudiées ont été observées. Les parasites correspondants sont indiqués entre parenthèses.

1 - Hněvice, rivière Elbe (Plumatella) ; 2 - Obříství, rivière Elbe (Branchiobdella) ; 3 - sandpit Lhota (Dreissena, Argulus) ; 4 - rivière Cidlina (Plumatella).

Selected parameters of water quality at studied localities are given in Table I.

The abbreviation TL used in the text indicates the total length of the crayfish body measured from the tip of the rostrum to the posterior margin of the telson.

\section{RESULTS}

\section{Branchiobdellidan worms}

We observed a high infestation of $O$. limosus by branchiobdellidan worms (Annelida: Branchiobdellida) in the river Elbe (Labe) at Obríství (upstream from the confluence with Vltava near Mělník) in May 2001. All larger specimens of crayfish (1 year and older) had numerous larger (over 6-7 mm - evidently B. parasita) and smaller branchiobdellidan worms. A mixed sample of the worms was collected from 3 crayfish specimens $-7,9$ and 17 worms, respectively. Altogether, 33 worms were collected and determined. Four European Branchiobdella species were identified: $B$. pentodonta (17 individuals, i.e. $52 \%$ of all worms), $B$. balcanica ( 8 inds $=24 \%)$, B. parasita $(6$ inds $=18 \%)$ and $B$. hexodonta $(2$ inds $=6 \%)$. These results were presented in the unpublished BSc thesis of ŽVAKOVÁ (2003). Additionally, 5 crayfish specimens carried branchiobdellidan egg cocoons attached to their shells. 


\section{Table I}

Selected environmental parameters measured in 2004 in localities with studied epibionts.

Tableau I

Sélection de paramètres environnementaux mesurés en 2004 dans des localités où des épibiontes ont été étudiés.

\begin{tabular}{|c|c|c|c|c|c|c|c|}
\hline Epibionts & Locality & Date & $\begin{array}{l}\text { Crayfish } \\
\text { collected }\end{array}$ & $\begin{array}{c}t \\
{\left[{ }^{\circ} \mathrm{C}\right]}\end{array}$ & $\mathrm{pH}$ & $\begin{array}{c}\text { cond. } \\
{[\mu \mathrm{S} / \mathrm{cm}]}\end{array}$ & $\begin{array}{c}\mathrm{O}_{2} \\
{\left[\mathrm{mg} \cdot \mathrm{I}^{-1}\right]}\end{array}$ \\
\hline \multirow{3}{*}{$\begin{array}{l}\text { Branchiobdella } \\
\text { spp. }\end{array}$} & \multirow{3}{*}{$\begin{array}{l}\text { Obríství (river Elbe) } \\
50^{\circ} 18^{\prime} 06 \mathrm{~N} \\
14^{\circ} 28^{\prime} 59 \mathrm{E}\end{array}$} & $21.05 .2004^{\star}$ & 25 & 17.0 & 8.0 & 469 & 10.7 \\
\hline & & $19.08 .2004^{*}$ & 35 & 24.9 & 8.0 & 551 & 9.5 \\
\hline & & $28.10 .2004^{\star}$ & 7 & 11.1 & 7.5 & 560 & 8.1 \\
\hline \multirow{5}{*}{$\begin{array}{l}\text { Dreissena } \\
\text { polymorpha } \\
\text { Argulus cf. } \\
\text { foliaceus }\end{array}$} & \multirow{5}{*}{$\begin{array}{l}\text { Lhota (sandpit) } \\
50^{\circ} 14^{\prime} 30 \mathrm{~N} \\
14^{\circ} 40^{\prime} 21 \mathrm{E}\end{array}$} & 10.06 .2004 & 4 & 23.6 & 8.2 & 693 & 11.4 \\
\hline & & 21.08 .2004 & 25 & 23.0 & 8.5 & 642 & 9.8 \\
\hline & & 30.09 .2004 & 13 & 15.1 & 8.2 & 669 & 9.7 \\
\hline & & 27.10 .2004 & 5 & 11.7 & 8.4 & 679 & 10.7 \\
\hline & & $28.04 .2005^{\star \star}$ & 16 & 13.7 & 7.9 & 705 & 10.5 \\
\hline \multirow[t]{2}{*}{$\begin{array}{l}\text { Plumatella } \\
\text { repens }\end{array}$} & $\begin{array}{l}\text { Hněvice (river Elbe) } \\
50^{\circ} 26^{\prime} 47 \mathrm{~N} \\
14^{\circ} 22^{\prime} 08 \mathrm{E}\end{array}$ & 01.10 .2004 & 36 & 16.3 & 8.2 & 423 & 12.2 \\
\hline & $\begin{array}{l}\text { Libice nad Cidlinou } \\
\text { (river Cidlina) } \\
50^{\circ} 07^{\prime} 25 \mathrm{~N} \\
15^{\circ} 10^{\prime} 50 \mathrm{E} \\
\end{array}$ & 20.05 .2004 & 17 & 18.1 & 8.2 & 710 & 10.4 \\
\hline
\end{tabular}

* No data are available from years 2001 and 2003, when branchiobdellidan worms occurred. ** Additional parameters were measured in water of the sandpit Lhota [mg. $\mathrm{I}^{-1}$ ]: $\mathrm{NH}_{4}{ }^{+}-3.4$, $\mathrm{NO}_{3}^{-}-8.6, \mathrm{Cl}^{-}-75.9, \mathrm{Ca}^{2+-} 400.8, \mathrm{Mg}^{2+-} 172$.

The position of the worms on the crayfish body is summarised in Figure 2. Most of them occurred on the outer and inner surfaces of the first three abdominal pleurae, and on bases of the walking legs. Worms were less abundant on the carapace and mouthparts, and only a few branchiobdellidans were present on chelae (dactylus and propodus), or on antennae.

Due to the strong summer flood in the watersheds of the Vltava and Elbe in 2002 we could not collect additional crayfish samples for studies on epibioses later that year. In July 2003, we observed an enormous decrease in spiny-cheek crayfish abundance at Obríství in comparison with the situation in 2001, which was clearly a consequence of the 2002 flood. Nevertheless, we succeeded in catching 16 crayfish specimens. Only one of them was found to bear branchiobdellidans ( 5 specimens of $B$. parasita - V. Bádr det; KRISTIAN, 2005). These were collected from bases of the walking legs, the carapace and the ventral abdomen. Egg cocoons were also present. Three other detached B. parasita were subsequently found in the bottle with the preserved crayfish.

Afterwards, we explored over 30 localities in the Elbe and Vltava drainage areas in 2003-2004, including multiple visits to the locality at Obříství, to check for the presence or absence of epibiotic worms. However, no O. limosus specimen was subsequently found to bear branchiobdellidans. 


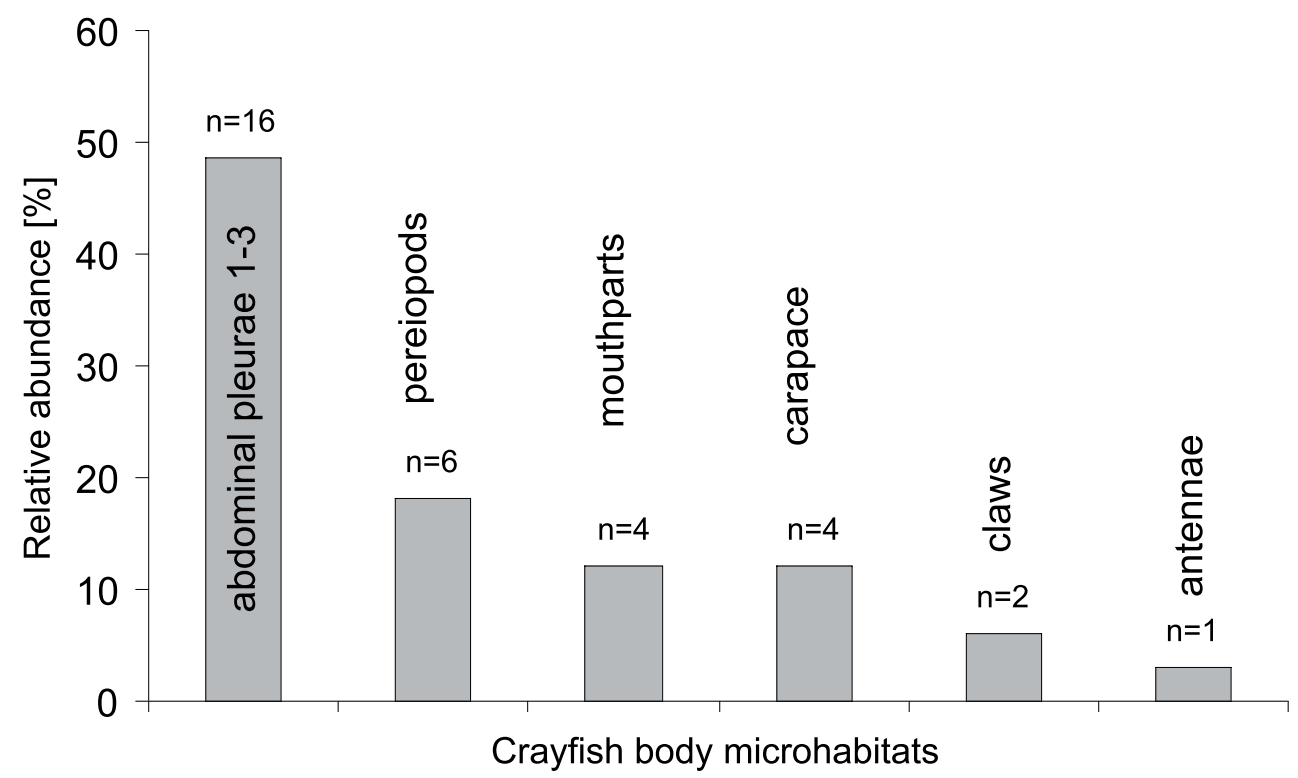

Figure 2

Relative abundance of specimens of branchiobdellidan worms on particular parts of Orconectes limosus body.

\section{Figure 2}

Relative abondance de spécimens de branchiobdellidés sur des parties spécifiques du corps d'un spécimen d'Orconectes limosus.

\section{Zebra Mussels}

The only Czech locality where crayfish were found to be colonised by the zebra mussel Dreissena polymorpha (Mollusca, Bivalvia) (Figure $3 \mathrm{~A}, \mathrm{~B}$ ) is the flooded sandpit Lhota near Brandýs nad Labem (an isolated water body in the Elbe watershed). Altogether, 42 crayfish specimens collected by scuba divers were examined in 2004, and 16 specimens in April 2005. Each of the four crayfish caught at the beginning of summer 2004 carried the mussels. In August, no crayfish carrying mussels large enough to be visible were collected, but very small juvenile mussels were observed in autumn (October) 2004. In spring 2005, almost all crayfish possessed young zebra mussels attached to their body.

A detailed examination of the zebra mussel sizes and microhabitats was performed with the material from April 2005. The number of molluscs per crayfish varied from 0 to 32 specimens (mean \pm SD: $9.6 \pm 10.3$ individuals). Highly preferred microhabitats for the zebra mussel attachment were: the ventral surface of the abdomen (39.2\%), the anterior ventral cephalothorax (mouthparts, epistome, basal articles of antennae and ventral rostrum - 13.7\%) and the anterior dorsal region of the carapace (13.7\%). In general, microhabitats on the ventral side of the crayfish body were more preferred $(65.4 \%)$ than on its dorsal surface. The young mussels were in most cases hidden in hollows under the abdominal pleurae, in the cervical groove, among spines on "cheeks" anterolaterally on the carapace, and in the mouth region. The size of the mussels varied mostly between 0.6 and $4.8 \mathrm{~mm}$, however, a single zebra mussel was larger, reaching $15 \mathrm{~mm}$ in shell length. 

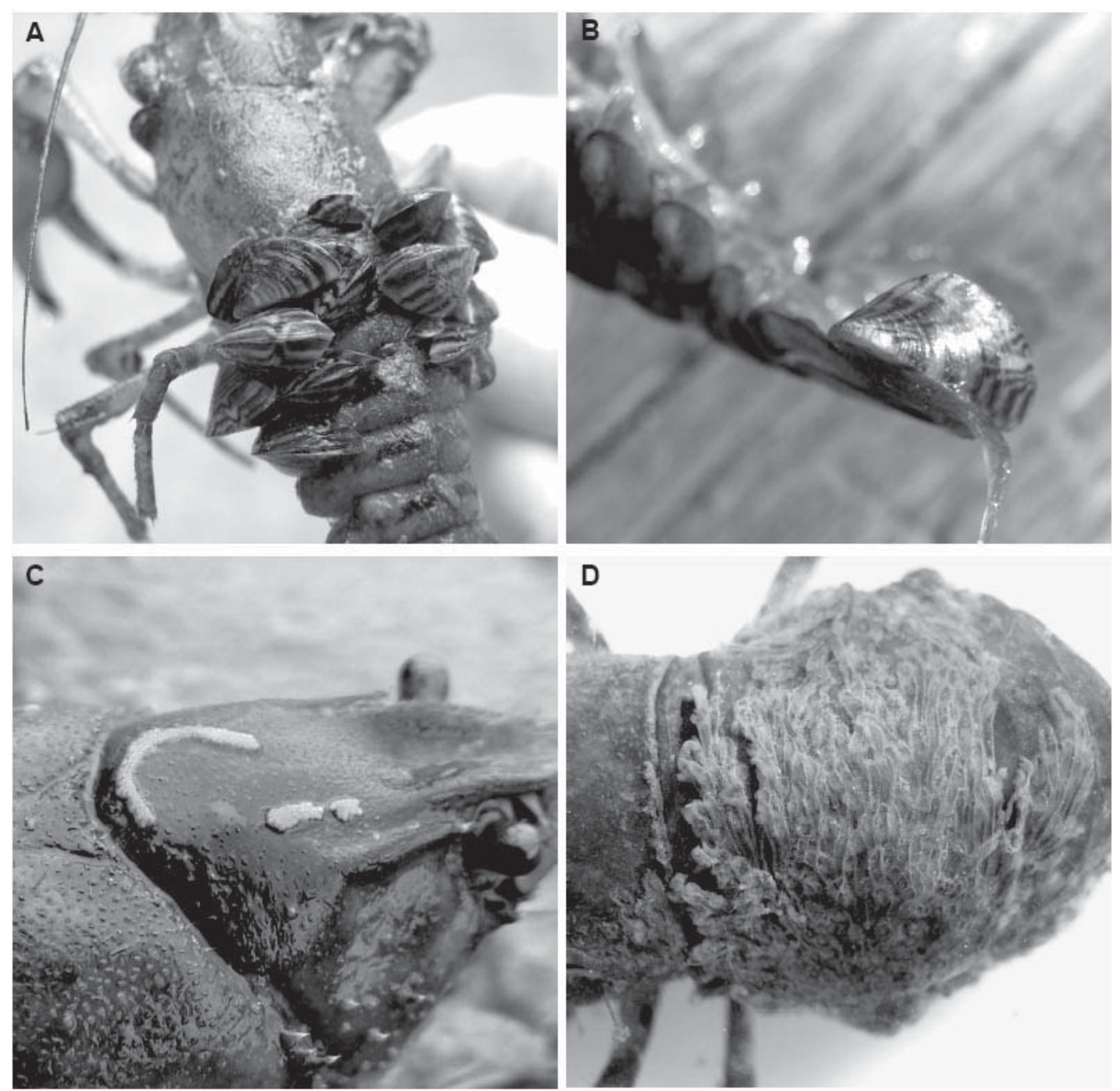

Figure 3

Epibiotic macroinvertebrates found on the spiny-cheek crayfish Orconectes limosus. A - Zebra mussel Dreissena polymorpha, Lhota sandpit near Brandýs nad Labem, 10 Jun. 2004. B - D. polymorpha (size $15 \mathrm{~mm}$ ) on crayfish uropod, Lhota, 28 Apr. 2005. C - Egg-strings of the fish louse Argulus cf. foliaceus, Lhota, 20 Aug. 2004. D - Bryozoan Plumatella repens, Hněvice near Štětí (Elbe River), 1 Oct. 2004.

Figure 3

Macroinvertébrés épibiotiques trouvés sur des Orconectes limosus. A - Moule Zebra Dreissena polymorpha, Lhota, carrière de sable près de Brandýs nad Labem, 10 juin. 2004. B - D. polymorpha (longueur corporelle $15 \mathrm{~mm}$ ) sur des uropodes d'écrevisses, Lhota, 28 avr. 2005. C - Chaîne d'œufs du pou du poisson Argulus cf. foliaceus, Lhota, 20 août 2004. D - Bryozoaire Plumatella repens, Hněvice près de Štětí (Rivière Elbe), 1 oct. 2004. 


\section{Fish louse eggs}

Egg strings of the fish louse Argulus cf. foliaceus (Crustacea: Branchiura) (Figure 3C) were found in the above-mentioned sandpit Lhota on 6 out of 25 Orconectes limosus specimens (24\%) collected in August 2004, and on 3 out of 13 crayfish (23\%) in September 2004. The frequency of crayfish carrying fish lice eggs increased to $63 \%$ (10 out of 16 collected individuals) at the end of April 2005. The egg-strings were laid only on the dorsal surface of the carapace (100\% of affected crayfish), abdomen (66\%) and telson $(6 \%)$. Most egg cases contained embryos in the latest stage of development, with welldeveloped eyes, or were empty, shortly after hatching of larvae. Both stages were often present in the same egg-string. Some of the strings had embryos with less developed eyes or in an even earlier stage, without eyespots.

\section{Bryozoans}

At least one bryozoan species, Plumatella repens (Bryozoa: Phylactolaemata), was found encrusting the spiny-cheek crayfish body surfaces. We observed this phenomenon in the river Elbe (Labe) near the village Hněvice in October 2004 (36 crayfish collected), and in the river Cidlina near its confluence with the Elbe in May 2004 (17 crayfish collected). One crayfish with an attached bryozoan was found at each of the localities. The crayfish collected in the Elbe (female, TL $81.5 \mathrm{~mm}$ ) had the bryozoan (Figure 3D) densely covering the anterior half of its abdomen (about $90 \%$ of tergites and pleura and about $80 \%$ of the ventral surface and pleopods of the $1^{\text {st }}-3^{\text {rd }}$ somites) and, partly (some short branches), on the region along the posterior margin of the carapace. Numerous floatoblasts in various stage of development, including almost full-grown ones, were present inside the cystids of the bryozoan colonies.

An ovigerous crayfish female from the river Cidlina (TL $91 \mathrm{~mm}$ ) bore two bryozoan colonies spread posteriorly on the dorsal and lateral carapace (about $40 \%$ of the carapace posterior to the cervical groove). The bryozoans were young colonies grown from statoblasts attached to the crayfish body the previous year. Remains of the statoblasts (including those which did not start to develop) were well visible under the colonies on the crayfish body surface.

\section{DISCUSSION}

Branchiobdellidans, the crayfish worms, are probably the best-known group of epibionts living in association with crayfish. Most branchiobdellidan species are regarded as epicommensals but some of them are parasites (GRABDA and WIERZBICKA, 1969). Some cause gill damage (VOGT, 1999) and evoke melanisation of gill filaments (ALDERMAN and POLGLASE, 1988). About 150 species of branchiobdellidans are known (GELDER, 1996), distributed in the Nearctic and two disjunctive Palearctic realms (GELDER, 1999). Studies on their associations frequently refer to native species of worms occurring on native crayfish species. Branchiodellids native to Europe belong to the endemic genus Branchiobdella (HOLT, 1975). Introduction of American crayfish Orconectes limosus, Pacifastacus leniusculus and Procambarus clarkii to Europe (LOWERY and HOLDICH, 1988) and their aggressive or mating behaviour has provided a possibility for exchange of associated epibionts with native crayfish species (GELDER et al., 1994). In North America, HOLT (1974) reported 1 branchiobdellidan species on $O$. limosus and three other on P. clarkii.

The first American branchiobdellidan species to be found on alien crayfish in European waters was Xironogiton instabilis, discovered on introduced $P$. leniusculus in Sweden (FRANZÉN, 1962) and later also in Austria (NESEMANN, 1998). Later, Cambarincola mesochoreus was found on $P$. clarkii, and $X$. victoriensis on $P$. leniusculus, in northern Italy (GELDER et al., 1994; QUAGLIO et al., 2002). On the other hand, two European crayfish worms, $B$. parasita and $B$. italica, were recently recorded from $P$. clarkii 
in northern Italy as well (GELDER et al., 1999). The present records of native European branchiobdellidan presence on American spiny-cheek crayfish $O$. limosus are among the first in Europe. Previously, as far as we know, only VOGT (1999) reported cases of the transmission of $B$. pentodonta and $B$. parasita to that crayfish species from the native Austropotamobius torrentium, but no details were given on the locality or year.

The total number of branchiobdellidans, as well as the number of host crayfish, decreased strongly in the locality Obříství after the first record of these worms in 2001, evidently because of the catastrophic flood on the river Elbe in summer 2002. Initially, 4 species, $B$. pentodonta, $B$. balcanica, $B$. parasita and $B$. hexodonta were determined in material from the year 2001 (ŽVAKOVÁ, 2003); later, in 2002 and 2003, only B. parasita was found. Interestingly, no branchiobdellidans have been confirmed on O. limosus in any other Czech locality. It seems likely that the temporary association of European worms on an American crayfish species was only occasional. It had to be caused by the previous contact of the alien crayfish population with a native species, presumably Astacus astacus, infested by branchiobdellidan worms. The worms are able to actively change hosts and also move from a native host (alive as well as just dead or moulted) to an alien species, at least from A. astacus to Pacifastacus leniusculus under experimental conditions (our observations, unpublished). Despite this, the phenomenon remains occasional and rare in Europe.

We have not found any native crayfish that may have been the source of branchiobdellidan worms at the studied locality. However, this does not invalidate the hypothesis of the direct transfer of epibionts from the native to the non-native species. The spiny-cheek crayfish (including those living in the river Elbe) are carriers of the crayfish plague pathogen in the Czech Republic (KOZUBÍKOVÁ et al., 2006), so if the two species came into contact, the native one may have died out because of this disease.

Although mixed material of worms collected in 2001 from three crayfish specimens was examined, the co-occurrence of more branchiobdellidan species on one host specimen was very likely. A similar co-occurrence was also repeatedly recorded on the native noble crayfish, Astacus astacus, in the Czech Republic (e.g. BÁDR, 2000; ŽVAKOVÁ, 2003; KRISTIAN, 2005). In North America, up to 7 branchiobdellidan species of four genera were reported from a single crayfish specimen (HOBBS et al., 1967).

The zebra mussel Dreissena polymorpha is an invasive bivalve mollusk of Pontocaspian origin that has spread mainly during the $20^{\text {th }}$ century to almost all countries of Europe and was also introduced to North America. It reached the Czech Republic from two directions - through the Danube and Morava rivers to southern Moravia (eastern part of the country), and by the Elbe from Germany to Bohemia (BERAN, 2002). This mollusk lives in dense populations on any available hard bottom. The planktonic larvae, veligers, settle predominantly on shells or near older zebra mussels (GRIFFITHS et al., 1989) but may use different substrates for their attachment.

In rare cases, the mussels may also settle on a crayfish exoskeleton (ROGERS et al., 2003). Examples have been previously reported from different countries and host species. The first observation was provided by LAURENT and SUSCILLON (1962) from a single specimen, a male (TL $95 \mathrm{~mm}$ ) of $O$. limosus caught in the Maine Department, France. More recently, this phenomenon was confirmed from the Lake of Geneva (Lac Léman) by LAURENT (1994). LAMANOVA (1971) reported zebra mussels attached to Astacus leptodactylus cubanicus - a crayfish species co-inhabiting at least a part of the original distribution area of the zebra mussel. ŚMIETANA (1996) recorded the occurrence of zebra mussels attached to O. limosus from the Dąbie Lake, Poland, and recently, LAJTNER et al. (2005), presented a poster with a photograph of $D$. polymorpha specimens attached to the dorsal carapace of $O$. limosus from Croatia. Although rare, the same phenomenon has also been observed in North America, for example from Lake Michigan (BRAZNER and JENSEN, 2000). The invasive zebra mussel occurred in this locality on the body of the rusty crayfish Orconectes rusticus. 
During our study of $O$. limosus in the Czech Republic, we surveyed about 60 localities in 2003-2004, covering most of the area known to be colonised by this species in the country (PETRUSEK et al., 2006). D. polymorpha co-occurs with crayfish in a number of these localities. The fact that crayfish were colonised by mussels in only one of them, the flooded sandpit Lhota near Brandýs nad Labem, as well as limited literature data, show that this phenomenon is rather rare. It is evident that in this particular case it occurred due to the lack of available hard substrates for larval veliger settlement, although other conditions (nutritional, temperature, water chemistry) at the locality are optimal for the zebra mussel population. The high calcium ion concentration, basic $\mathrm{pH}$, summer temperatures up to $25^{\circ} \mathrm{C}$, absence of spring algal bloom and round-year clean water indicate moderate trophic relations. All these environmental data are well comparable with published information on D. polymorpha requirements (McMAHON, 1996; BOWMAN and BAILEY, 1998; TOOMEY et al., 2002).

The frequency of colonised crayfish in the present locality reached up to $100 \%$ in the beginning of summer 2004, and almost as high in April 2005. These values are remarkably high in comparison with previous observations. LAURENT and SUSCILLON (1962) reported only one crayfish specimen bearing a mussel, ŚMIETANA (1996) found $D$. polymorpha on 6 out of 600 (i.e. 1\%) examined specimens of O. limosus, BRAZNER and JENSEN (2000) recorded 6 specimens of the rusty crayfish Orconectes rusticus colonized with the zebra mussel out of approximately 25-50 captured specimens.

In August 2004, no crayfish were carrying the mussels in our studied locality. It is clear that this unusual relationship is only occasional and facultative. The crayfish probably lost all the bivalves by moulting during summer. New mussels appeared by late summer and early autumn by settlement of planktonic veliger larvae. Active movement of postlarvae, well documented in literature (TOOMEY et al., 2002), may contribute to the colonisation of the crayfish body surface but probably plays a minor role because of the host's higher mobility and self-cleaning behavior. The ventral surfaces of the crayfish abdomen, telson and uropods, as well as the dorsal tail fan, however, are well available for young mussels' active transposition from the bottom to resting crayfish. The presence of one large (15 mm long) zebra mussel attached ventrally to the posterior margin of a crayfish uropod (May 2005 - Figure 3B) demonstrates the mussels' ability to actively move and attach to the crayfish body. The mussel specimen was certainly more than one-year old (when compared with data of GARTON and JOHNSON, 2000), although its crayfish host had lost its old exoskeleton by moulting during the previous summer.

The microhabitats preferred by zebra mussels for colonizing crayfish exoskeletons are interesting. Our material from O. limosus examined in detail in May 2005 differs significantly from data of BRAZNER and JENSEN (2000) on epibiosis on O. rusticus. While the American authors refer to the chelae, telson and uropods, and carapace as the most heavily colonized parts of crayfish body, in our case the mussels highly preferred the ventral abdomen. Our previous (June 2004) observations and photos made in the same locality, however, indicate that larger (approx. one-year old) mussels were concentrated mainly on the anterior dorsal surface of the abdomen, although some remained on both the ventral abdomen and telson, and the anterior dorsal cephalothorax. As this contrasts with our spring data, it indicates that the mussels may be able to translocate during their growth to a more suitable position on the crayfish body. By that time, the mussels are larger and their attachment by byssus is strong enough to withstand the host's cleaning by the slender second and third cheliform pereiopods.

This rarely reported phenomenon of a crayfish body being colonised by the zebra mussels occurred, as noted above, due to the lack of hard substrate in the locality. Similarly, females of the carp louse Argulus foliaceus deposit narrow, 2 to 6-rowed strings of eggs (PASTERNAK et al., 2000) on a variety of substrates, including sometimes crayfish 
shells, as observed by us in the same locality. This phenomenon seems to be also unusual. Only recently has it been recorded from the European crayfish Astacus leptodactylus in Poland (ŚMIETANA and WIERZBICKA, 1998; WIERZBICKA and ŚMIETANA, 1999) and in the Czech Republic (HORKÁ, 2003). Clearly, this is not in any way a host-specific behaviour, as in our case we confirmed occasional egg laying by European fish lice also on the body surface of an American crayfish species.

The duration of the life cycle of the carp louse $A$. foliaceus depends on the water temperature; it lasts a minimum of 8 weeks and there can be several generations per year (DYK, 1961; PASTERNAK et al., 2000). In Finland, the most distinct peak of occurrence of A. foliaceus larvae in plankton was observed at the end of May (PASTERNAK et al., 2000). As the Czech Republic is located in the more temperate climate of Central Europe, this timing of season agrees well with our data on the presence of empty cocoons from freshly hatched larvae, as well as of some remaining embryos of the metanauplius stage just before hatching, sometimes in the same string as empty cocoons, at the end of April.

Bryozoan colonies were rarely found on crayfish during our research course in 2004. At least in two cases Plumatella repens was found densely covering parts of the spinycheek crayfish body, dorsally and ventrally on the abdomen and dorsally on the posterior cephalothorax, leaving the connection of the body parts free for moving. We found only brief notices of similar cases in the literature. ŠTÉPÁN (1932-33) pointed attention to the possibility of bryozoan statoblast attachment to a crayfish body, and the growth of colonies on their exoskeletons. An uncommented notice on bryozoans was given also by ALDERMAN and POLGLASE (1988). ADÁMEK and ŘEHULKA (2000) reported on P. repens colonizing another American crayfish species in the Czech Republic, the signal crayfish Pacifastacus leniusculus; In some cases the crayfish died during moulting, which was caused by the extensive coverage of densely grown compact bryozoan colonies.

The growth of bryozoans on crayfish is limited by two main factors affecting such an occasional association - the moulting of adult crayfish in summer, and the termination of the bryozoan life cycle in winter. To reach the coverage of the crayfish body observed by us as well as previous authors, the growth of bryozoan colonies must be very fast. The related bryozoan species, Plumatella fungosa, is known to produce at least 3 generations of colonies annually (KAMIŃSKI, 1992). Our material well illustrates fast growth rates, showing old, adult colonies in autumn and young, freshly grown colonies in spring.

\section{ACKNOWLEDGEMETS}

We would like to thank V. Bádr (University of Hradec Králové) and L. Žvaková (University of Ostrava) for providing some of the data from branchiobdellidan analyses, J.W. Fetzner (Brigham Young University, Provo) and W.D. Daniels (Auburn University) for help with literature, A. Petrusek (Charles University, Prague) for valuable comments, C. D'Udekem d'Acoz (University of Trondheim) for translations to French, and D. Hardekopf for language corrections. Two anonymous opponents provided comments, which improved the previous version of the manuscript. The research was supported by the Czech Science Foundation project GAČR 206/03/0532.

\section{REFERENCES}

ADÁMEK Z., ŘEHULKA J., 2000. Crayfishes diseases and commensals found in the Czech Republic in 1998. Bulletin VúRH Vodňany, 36(1/2), 28-32 [Czech].

ALDERMAN D.J., POLGLASE J.L., 1988. Pathogens, parasites and commensals. In: LOWERY R.S., HOLDICH D.M. (eds.), Freshwater Crayfish: Biology, Management and Exploitation. Croom Helm, London and Sydney, and Timber Press, Portland, Oregon, 367-379. 
BÁDR V., 2000. A preliminary report on branchiobdellidans (Annelida: Clitellata) from Czech Republic and their possible pathogenity. Bulletin VúRH Vodňany, 36(1/2), 33-40 [Czech].

BERAN L., 2002. Aquatic molluscs of the Czech Republic - distribution and its changes, habitats, dispersal, threat and protection, Red List. - Sborník přírodovědného klubu v Uherském Hradišti, Supplementum, 10, 258 p. [Czech].

BOWMAN M.F., BAILEY R.C., 1998. Upper pH tolerance limit of the zebra mussel (Dreissena polymorpha). Canadian Journal of Zoology, 76(11), 2119-2123.

BRAZNER J.C., JENSEN D.A., 2000. Zebra Mussel (Dreissena polymorpha [Pallas]) Colonization of Rusty Crayfish (Orconectes rusticus [Girard]) in Green Bay, Lake Michigan, University of Minnesota. American Midland Naturalist, 143(1), 250-256.

DYK V., 1961. Nemoci ryb [Fish diseases]. ČSAZV, Prague, 404 p. [Czech].

EDGERTON B.F., EVANS L.H., STEPHENS F.J., OVERSTREET R.M., 2002. Synopsis of freshwater crayfish diseases and commensal organisms. Aquaculture, 206, 57-135.

EDGERTON B.F., HENTTONEN P., JUSSILA J., MANNONEN A., PAASONEN P., TAUGBØL T., EDSMAN L., SOUTY-GROSSET C., 2004. Understanding the causes of disease in European freshwater crayfish. Conservation Biology, 18, 1466-1474.

EVANS L.H., EDGERTON B.F., 2002. Pathogens, Parasites and Commensals. In HOLDICH D.M. (ed.), Biology of Freshwater Crayfish, 377-423. Blackwell Science, Oxford.

FRANZÉN A., 1962. Notes on the morphology and histology of Xironogiton instabilis (Moore, 1893) (Fam. Branchiobdellidae) with special reference to the muscle cells. Zoologiska Bidrag från Uppsala, 35, 369-383.

GARTON D.W., JOHNSON L.E., 2000. Variation in growth rates of the zebra mussel, Dreissena polymorpha, within Lake Wawasee. Freshwater Biology, 45, 443-451.

GELDER S.R., 1996. A review of the taxonomic nomenclature and a checklist of the species of the Branchiobdellae (Annelida: Clitellata). Proceedings of the Biological Society of Washington, 109, 653-663.

GELDER S.R., 1999. Zoogeography of branchiobdellidans (Annelida) and temnocephalidans (Platyhelminthes) ectosymbiotic on freshwater crustaceans, and their reactions to one another in vitro. Hydrobiologia, 406, 21-31.

GELDER S.R., DELMASTRO G.B., FERRAGUTI M., 1994. A report on branchiobdellidans (Annelida: Clitellata) and a taxonomic key to the species in northern Italy, including the first record of Cambarincola mesochoreus on the introduced American red swamp crayfish. Bolletino di Zoologia, 61, 179-183.

GELDER S.R., DELMASTRO G.B., RAYBURN J.N., 1999. Distribution of native and exotic branchiobdellidans (Annelida: Clitellata) on their respective crayfish hosts in northern Italy, with the first record of native Branchiobdella species on an exotic North American crayfish. Journal of Limnology, 58(1), 20-24.

GRABDA E., WIERZBICKA J., 1969. The problem of parasitism of the species of the genus Branchiobdella Odier, 1823. Polskie Archivum Hydrobiologii, 16/29(1), 93-104.

GRIFFITHS R.W., KOVALAK W.P., SCHLOESSER D.W., 1989. The Zebra Mussel, Dreissena polymorpha (Pallas, 1997), in North America: Impact On Raw Water Users. In: EPRI Service Water System Reliability Improvement Seminar: Papers, 11-27. Electric Power Research Institute, Palo Alto, California. 
HOBBS H.H. JR., HOLT P.C., WALTON M., 1967. The crayfishes and their epizootic ostracod and branchiobdellid associates of the Mountain Lake, Virginia, region. Proceedings of the United States National Museum, 123, 1-84.

HOLT P.C., 1974. The genus Xironogiton Ellis, 1919 (Clitellata: Branchiobdellida). The Virginia Journal of Sciences (new series), 25(1), 5-19.

HOLT P.C., 1975. The branchiobdellid (Annelida: Clitellata) associates of astacoidean crawfishes. Freshwater Crayfish, 2, 337-345.

HORKÁ I., 2003. The distribution, growth-weight relations and ecology of narrow-clawed crayfish (Pontastacus leptodactylus) in Karviná District. Bachelor paper, University of Ostrava, 43 p. [Czech].

KAMIŃSKI M., 1992. Life cycle of the freshwater bryozoan Plumatella fungosa (Pall.). 1. Seasonal changes in numbers and biomass. Acta Hydrobiologica, 34, 227-238.

KOZUBíKOVÁ E., PETRUSEK. A., ĎURIŠ Z., KOZÁK P., GEIGER S., HOFFMANN R., OIDTMANN B., 2006. The crayfish plague in the Czech Republic. Review of recent suspect cases and a pilot detection study. Craynet, Vol. 4, Bull. Fr. Pêche Piscic., 380-381, 1313-1324.

KRISTIAN J., 2005. On the occurrence and ecology of the genus Branchiobdella (Annelida, Clitellata) in selected regions of the Czech Republic. Unpublished Bachelor thesis, University of Ostrava, 38 p. [Czech].

LAJTNER J., KLOBUČAR G.I.V., MAGUIRE I., LUCIĆ A., ŠTAMBUK A., ERBEN R., 2005. They came from the Danube River - History and present status of Dreissena polymorpha and Orconectes limosus in Croatia. INWAT: Biological invasions in inland waters. Firenze, May 5-7, 42-43. [abstr.].

LAMANOVA A I.,1971. Attachment by zebra mussels and acorn barnacles on crayfish. Gidrobiologicheski Zhurnal, 6, 105-107.

LAURENT P. J., 1994. Zebra mussels on crayfish. IAA Newsletter, 16(4), 4-5.

LAURENT P.J., SUSCILLON M., 1962. Les écrevisses en France. Annales de la Station Centrale d'Hydrobiologie Appliquée, 9, 333-395, 1 map.

LOWERY R.S., HOLDICH D.M., 1988. Pacifastacus leniusculus in North America and Europe, with details of the distribution of introduced and native crayfish species in Europe. In: D.M. HOLDICH, R.S. LOWERY (eds.), Freshwater Crayfish: Biology, Management and Exploitation. Croom Helm, London and Sydney, and Timber Press, Portland, Oregon, 283-308.

McMAHON R.F., 1996. The physiological ecology of the zebra mussel, Dreissena polymorpha, in North America and Europe. American Zoologist, 36, 339-363.

NESEMANN H., 1998. Flußkrebse und Krebsegel (Annelida: Branchiobdellida) - eine Symbiose. Stapfia, Neue Folge, 137, 197-204.

PASTERNAK A., MIKHEEV V.N., VALTONEN E.T., 2000. Life history characteristics of Argulus foliaceus L. (Crustacea: Branchiura) populations in Central Finland. Annales Zoologici Fennici, 37, 25-35.

PETRUSEK A., FILIPOVÁ L., ĎURIŠ Z., HORKÁ I., KOZÁK P., POLICAR T., ŠTAMBERGOVÁ M., KUČERA Z., 2006. Distribution of the invasive spiny-cheek crayfish (Orconectes limosus) in the Czech Republic. Past and present. Craynet, Vol. 4, Bull. Fr. Pêche Piscic., 380-381, 903-918.

QUAGLIO F., FIORAVANTI M.L., GELDER S.R., GIANNETTO S., TRENTINI M., NOBILE L., MAXIA M., MOROLLI C., 2002. Infestation of the branchiobdellidan, Xironogiton 
victoriensis (Anellida: Clitellata) on the signal crayfish (Pacifastacus leniusculus) from Auenbachl Creek, Alto Adige/Süd Tyrol, Italy. Freshwater Crayfish, 13, 275-279.

ROGERS D., HOFFMANN R., OIDTMANN B., 2003. Diseases in selected Austropotamobius pallipes populations in England., In HOLDICH D.M., SIBLEY P.J. (eds.), Management \& Conservation of Crayfish. Proceedings of a conference, Nottingham Forest Football Club, 7 Nov. 2002, 169-174. Nottingham, UK. Environment Agency, Bristol.

ŚMIETANA P., 1996. Attachment of zebra mussel, Dreissena polymorpha (Pall.) to the exoskeleton of Orconectes limosus (Raf.) from the Dąbie Lake. Przeglad Zoologiczny, 40(1-2), 69-72 [Polish, Eng. abstr].

ŚMIETANA P., WIERZBICKA J., 1998. Crayfish (Astacus astacus and Astacus leptodactylus) of Polish origin as habitat of Oligochaeta and Crustacea. XII International Symposium of IAA, Augsburg, Germany, 3-9 Aug. 1998, Abstract volume, 68.

ŠTĚPÁN V.J., 1932-33. Soudobý stav rakařství v Čechách [Recent state of crayfish farming in Bohemia]. Separate reprint from Československý rybáŕ, 1-21 [Czech].

TOOMEY M.B., McCABE D., MARSDEN J.E., 2002. Factors affecting the movement of adult zebra mussels (Dreissena polymorpha). Journal of the North American Benthological Society, 21(3), 468-475.

VOGT G., 1999. Diseases of European freshwater crayfish, with particular emphasis on interspecific transmission of pathogens. In: GHERARDI F., HOLDICH D.M. (eds.), The introduction of alien species of crayfish in Europe: How to make the best of a bad situation? Crustacean Issues, 11, 87-103. A.A. Balkema, Rotterdam.

WIERZBICKA J., ŚMIETANA P., 1999. The food of Branchiobdella Odier, 1823 (Annelida) dwelling on crayfish and the occurrence of the fish parasite Argulus Muller, 1785 (Crustacea) on the carapace of Pontastacus leptodactylus (Esch.). Acta Ichthyologica et Piscatoria, 29(1), 95-99.

ŽVAKOVÁ L., 2003. Worms of the genus Branchiobdella (Annelida: Clitellata) and their relations to crayfish species in the Czech Republic. Unpublished Bachelor thesis, University of Ostrava, 43 p. [Czech]. 
